\title{
Long-term Antidepressant Administration Alters Corticotropin-releasing Hormone, Tyrosine Hydroxylase, and Mineralocorticoid Receptor Gene Expression in Rat Brain
}

\section{Therapeutic Implications}

Linda S. Brady, Harvey J. Whitfield, Jr., Robert J. Fox, Philip W. Gold, and Miles Herkenham

Section on Functional Neuroanatomy, Clinical Neuroendocrinology Branch,

National Institute of Mental Health, Bethesda, Maryland 20892

\begin{abstract}
Imipramine is the prototypic tricyclic antidepressant utilized in the treatment of major depression and exerts its therapeutic efficacy only after prolonged administration. We report a study of the effects of short-term ( $2 \mathrm{wk})$ and long-term (8 wk) administration of imipramine on the expression of central nervous system genes among those thought to be dysregulated in imipramine-responsive major depression. As assessed by in situ hybridization, 8 wk of daily imipramine treatment $(5 \mathrm{mg} / \mathrm{kg}$, i.p. $)$ in rats decreased corticotropin-releasing hormone (CRH) mRNA levels by $37 \%$ in the paraventricular nucleus (PVN) of the hypothalamus and decreased tyrosine hydroxylase (TH) mRNA levels by $40 \%$ in the locus coeruleus (LC). These changes were associated with a $70 \%$ increase in $\mathrm{mRNA}$ levels of the hippocampal mineralocorticoid receptor (MR, type I) that is thought to play an important role in mediating the negative feedback effects of low levels of steroids on the hypothalamicpituitary-adrenal (HPA) axis. Imipramine also decreased proopiomelanocortin (POMC) mRNA levels by $38 \%$ and glucocorticoid receptor (GR, type II) mRNA levels by $51 \%$ in the anterior pituitary. With the exception of a $20 \%$ decrease in $\mathbf{T H}$ mRNA in the LC after 2 wk of imipramine administration, none of these changes in gene expression were evident as a consequence of short-term administration of the drug. In the light of data that major depression is associated with an activation of brain CRH and LC-NE systems, the time-dependent effect of long-term imipramine administration on decreasing the gene expression of CRH in the hypothalamus and TH in the LC may be relevant to the therapeutic efficacy of this agent in depression. (J. Clin. Invest. 1991. 87:831-837). Key words: depression • glucocorticoid receptor $\bullet$ imipramine $\bullet$ mRNA $\bullet$ pro-opiomelanocortin
\end{abstract}

\section{Introduction}

Tricyclic antidepressant drugs are widely used in the treatment of major depression and generally exert their therapeutic efficacy only after 3-5 wk of daily administration (1). Many neuro-

Data in this paper were presented in part at the 19th Annual UCLA Symposia on Molecular and Cellular Biology, Molecular Biology of Neurotransmitters and Their Receptors, 17 April 1990 (Whitfield, H. J., Jr., L. S. Brady, R. J. Fox, P. W. Gold, and M. Herkenham. 1990. J. Cell. Biochem. 14F:41. [Abstr.]).

Address correspondence and reprint requests to Linda S. Brady, Section on Functional Neuroanatomy, NIMH, Bldg. 36, Room 2D-15, Bethesda, MD 20892.

Received for publication 21 May 1990 and in revised form $15 \mathrm{Au}$ gust 1990.

The Journal of Clinical Investigation, Inc.

Volume 87, March 1991, 831-837 chemical and pharmacological effects of tricyclic antidepressant administration have been reported, such as inhibition of monoamine reuptake, down-regulation, and desensitization of $\beta$-adrenergic and 5- $\mathrm{HT}_{2}$ receptors, and alterations in $\alpha$-adrenergic, dopaminergic, and $\gamma$-aminobutyric acid receptors (for review, see reference 1). Most of these effects have been observed after 7-21 d of antidepressant administration, a time period which is shorter than that necessary to achieve full therapeutic efficacy. Hence, it is unclear how these neurochemical and pharmacological effects are related to the time period required to achieve therapeutic efficacy of antidepressant drugs in patients with major depression.

We report a study that compares the effects of short-term (2 wk) and long-term ( $8 \mathrm{wk}$ ) administration of the prototypic tricyclic antidepressant imipramine on central nervous system gene expression in unstressed rats as assessed by in situ hybridization. Because a consistent biological finding in patients with major depression is activation of central corticotropin-releasing hormone $(\mathrm{CRH})^{1}(2-4)$ and the locus coeruleus-NE system $(5,6)$, we focused our study on the time-dependent effects of imipramine on the gene expression of $\mathrm{CRH}$ in the paraventricular nucleus (PVN) of the hypothalamus and tyrosine hydroxylase (TH) in the locus coeruleus (LC). Because the mineralocorticoid receptors (MR, type I) and glucocorticoid receptors (GR, type II) in the hippocampus appear to mediate the negative feedback effect of steroids on the hypothalamic-pituitaryadrenal (HPA) axis (7-10), we assessed the time-dependent effects of imipramine on the expression of these genes as well. Finally, to assess the time-dependent effects of steroids on pituitary-adrenal function, we examined the gene expression of pro-opiomelanocortin (POMC) and GR in the anterior pituitary and the secretion of $\mathrm{ACTH}$ and corticosterone into plasma.

\section{Methods}

Animals. Male Sprague-Dawley rats (175-200 g, Taconic Farms, Germantown, NY) were housed three per cage at $24^{\circ} \mathrm{C}$ with lights on from 0600 to $1800 \mathrm{~h}$. Rats were randomly separated into control and experimental groups and weighed weekly. Experimental animals were injected with imipramine hydrochloride $(5 \mathrm{mg} / \mathrm{kg}$ dissolved in $0.9 \%$ saline; Sigma Chemical Co., St. Louis, MO) i.p. daily at $0900 \mathrm{~h}$ for 2 or 8 wk. Control animals consisted of rats injected similarly with $0.9 \%$ saline and noninjected rats that were handled daily.

Animals were sacrificed between 1000 and $1100 \mathrm{~h}, \sim 1 \mathrm{~h}$ after the last injection of saline or imipramine. Brains were removed, frozen by

1. Abbreviations used in this paper: $\mathrm{CRH}$, corticotropin-releasing hormone; GR, glucocorticoid receptor; HPA, hypothalamic-pituitaryadrenal; LC, locus coeruleus; MR, mineralocorticoid receptor; POMC, pro-opiomelanocortin: $\mathrm{PVN}$, paraventricular nucleus; $\mathrm{TH}$, tyrosine hydroxylase. 
immersion in 2 -methyl butane at $-30^{\circ} \mathrm{C}$, and stored at $-70^{\circ} \mathrm{C}$ before sectioning. Frozen sections ( $15 \mu \mathrm{m}$ thick) were cut coronally through the PVN, dorsal hippocampus, pituitary, and LC. Trunk blood was collected on ice, centrifuged, and frozen at $-70^{\circ} \mathrm{C}$. ACTH and corticosterone were measured by RIA (ACTH by method of reference 11 and corticosterone using ICN Biochemicals kit, Cleveland, OH), and imipramine and its metabolite, desipramine, were measured by HPLC (12). The intraassay and interassay coefficients of variance were $<10 \%$.

In situ hybridization. Synthetic 48-base oligodeoxyribonucleotide probes (generously donated by W. Scott Young III, Laboratory of Cell Biology, National Institute of Mental Health) were directed against: CRH (bases 496-543 [13]), POMC (bases encoding amino acids 96111 [14]), and TH (bases 1441-1488 [15]). The probes were labeled at the 3 '-end using $\left[\alpha^{-35}\right.$ S $]$ dATP (sp act $>1,000 \mathrm{Ci} / \mathrm{mmol}$, New England Nuclear, Boston, MA), terminal deoxynucleotidyl transferase $(25 \mathrm{U} / \mu \mathrm{l}$, Boehringer-Mannheim Biochemicals, Indianapolis, IN) and tailing buffer (Bethesda Research Laboratory, Bethesda, MD); sp act of the probes was $4-10 \times 10^{3} \mathrm{Ci} / \mathrm{mmol}$.

Ribonucleotide probes (plasmids generously donated by Jeffrey L. Arriza, The Salk Institute) were directed against bases 81-528 of the rat GR sequence (16) and 513 bases encoding the carboxy-terminal 25 amino acids and a portion of the 3 -untranslated region of the rat MR sequence (17). Transcription of antisense and sense probes was carried out using the Riboprobe System (Promega Biotech, Madison, WI) in the presence of $\left[\alpha^{-3} \mathrm{~S}\right] \mathrm{UTP}$ (sp act $1,000-1,500 \mathrm{Ci} / \mathrm{mmol}$, New England Nuclear).

In situ hybridization histochemistry was performed as previously described $(18,19)$. Briefly, sections were incubated overnight at $37^{\circ} \mathrm{C}$ with $5 \times 10^{5} \mathrm{cpm}$ of labeled CRH, POMC, or TH probe, washed in four 15 -min rinses of $2 \times \operatorname{SSC}(1 \times$ SSC is $0.15 \mathrm{M}$ sodium chloride, $0.015 \mathrm{M}$ sodium citrate, $\mathrm{pH} 7.2$ ) containing $50 \%$ formamide at $40^{\circ} \mathrm{C}$, two 30 min rinses of $1 \times \mathrm{SSC}$ at $25^{\circ} \mathrm{C}$, briefly rinsed in distilled water, $70 \%$ ethanol, and dried. Sections were incubated overnight at $53^{\circ} \mathrm{C}$ with 5 $\times 10^{5} \mathrm{cpm}$ of labeled MR or GR probe, treated with RNase A (20 $\mu \mathrm{g} / \mathrm{ml}$, Boehringer-Mannheim Biochemicals) for $30 \mathrm{~min}$ at $25^{\circ} \mathrm{C}$, washed sequentially for $60 \mathrm{~min}$ in $2 \times \mathrm{SSC}$ at $50^{\circ} \mathrm{C}, 60 \mathrm{~min}$ in $0.2 \times \mathrm{SSC}$ at $55^{\circ} \mathrm{C}$, and $60 \mathrm{~min}$ in $0.2 \times \mathrm{SSC}$ at $60^{\circ} \mathrm{C}$, briefly rinsed in a graded series of ethanol containing $0.3 \mathrm{M}$ ammonium acetate, and dried. $\mathrm{Hy}$ bridization of adjacent sections with labeled MR or GR sense probes produced a uniform, low signal which was barely visible on film (19).

Slides and ${ }^{35} \mathrm{~S}$-impregnated brain paste standards of known radioactivity and wet weight were placed in x-ray cassettes, apposed to film (Hyperfilm- $\beta$ Max, Amersham Corp., Arlington Heights, IL) for 1-7 d ( 4 wk for MR in the pituitary; 6 wk for MR in the PVN) and developed (D19, Kodak) for $5 \mathrm{~min}$ at $20^{\circ} \mathrm{C}$. To determine anatomical localization of probe at the cellular level, sections were dipped in NTB-2 nuclear emulsion (Eastman Kodak Co., Rochester, NY) as described previously $(20,21)$, exposed for 1-9 d, developed (D19, Eastman Kodak Co.) for $2 \mathrm{~min}$ at $16^{\circ} \mathrm{C}$, and counterstained with cresyl violet.

Data analysis. Autoradiographic film images of brain sections and ${ }^{35}$ S-standards were digitized on a Macintosh II computer-based image analysis system with IMAGE software (Wayne Rasband, Research Services Branch, National Institute of Mental Health). Light transmittance of probe hybridized in each brain region was measured by outlining the structure with the mouse cursor. A calibration curve was constructed using the transmittance values of ${ }^{35} \mathrm{~S}$-brain paste standards containing known amounts of radioactivity. Transmittance measurements for each probe were made on two consecutive sections per rat and were converted to disintegrations per minute per milligram wet weight of tissue using the calibration curve. The average value for each of six animals per experimental or control group was used to calculate group means $(n=6)$. The relative amount of probe hybridized in each brain region of the imipramine-treated animals is expressed as a percentage of the respective 2-wk or 8-wk saline-injected control groups. Statistical significance between control and experimental groups was determined by one-way analysis of variance and unpaired, two-tailed $t$ test. No statistical difference was found in the amount of various probes hybridized in each brain region or in the plasma ACTH and corticosterone values between saline-injected and noninjected control rats.

\section{Results}

Effects of daily imipramine on TH MRNA levels in the LC. After 2 wk of chronic imipramine administration $(5 \mathrm{mg} / \mathrm{kg}$, i.p.) TH gene expression was decreased by $20 \%$ in the LC (Table I, Fig. 1). No other changes in brain mRNA levels were evident after 2 wk. TH mRNA levels were decreased by an additional $20 \%$ after 8 wk of drug.

Effects of daily imipramine on MR and GR mRNA levels in the hippocampus. After $8 \mathrm{wk}$ of chronic imipramine administration MR but not GR gene expression was selectively altered in the dorsal hippocampus (Table I). Levels of MR mRNA were increased a similar amount in the four CA fields and the dentate gyrus in imipramine-treated animals relative to control. Fig. 2 shows autoradiographic labeling of MR mRNA within neurons in the hippocampal CAl region in 8-wk treated and control animals. MR expression was not altered in other brain regions (Table I).

Effects of daily imipramine on CRH, GR, and MR $m R N A$ levels in the PVN of the hypothalamus. Chronic imipramine administration decreased gene expression of CRH but not that of GR or MR in the PVN (Table I). CRH mRNA levels were reduced by $37 \%$ in the parvocellular region of the PVN (Fig. 3). This change was seen only after 8 wk of chronic imipramine.

Effects of daily imipramine on POMC, GR, and MR $m R N A$ levels in the pituitary. Gene expression of POMC and GR was reduced in the anterior lobe of the pituitary after $8 \mathrm{wk}$ of imipramine administration (Table I, Fig. 4). POMC mRNA levels were decreased by $37 \%$ in corticotroph cells in the anterior lobe

Table I. Expression of $m R N A$ in Rat Brain after Chronic Imipramine

\begin{tabular}{lccc}
\hline \multicolumn{1}{c}{ Brain region } & Control & $\begin{array}{c}\text { Imipramine } \\
2 \mathbf{w k}\end{array}$ & $\begin{array}{c}\text { Imipramine } \\
8 \mathbf{w k}\end{array}$ \\
\hline $\begin{array}{l}\text { Hippocampus } \\
\text { MR }\end{array}$ & & & \\
GR & $100 \pm 18$ & $130 \pm 31$ & $170 \pm 22^{\ddagger}$ \\
PVN & $100 \pm 5$ & $96 \pm 5$ & $104 \pm 5$ \\
CRH & & & \\
GR & $100 \pm 14$ & $104 \pm 11$ & $63 \pm 15^{\S}$ \\
MR & $100 \pm 24$ & $73 \pm 41$ & $72 \pm 33$ \\
Pituitary, anterior lobe & $100 \pm 10$ & $96 \pm 4$ & $92 \pm 7$ \\
POMC & $100 \pm 30$ & $82 \pm 24$ & $62 \pm 31^{*}$ \\
GR & $100 \pm 46$ & $52 \pm 47$ & $49 \pm 14^{*}$ \\
MR & $100 \pm 20$ & $95 \pm 12$ & $104 \pm 9$ \\
Pituitary, intermediate lobe & & & \\
POMC & $100 \pm 3$ & $101 \pm 1$ & $100 \pm 2$ \\
MR & $100 \pm 24$ & $117 \pm 32$ & $130 \pm 35$ \\
Locus coeruleus & & & \\
TH & $100 \pm 18$ & $80 \pm 8^{*}$ & $60 \pm 11^{\ddagger}$ \\
GR & $100 \pm 15$ & $90 \pm 11$ & $101 \pm 16$ \\
\hline
\end{tabular}

Values are mean and $\operatorname{SD}(n=6)$ expressed as percentage of the respective 2-wk or 8-wk saline-injected control. SD of the control group is given for the 8-wk animals. ${ }^{*} P<0.03 ;{ }^{\ddagger} P<0.003 ;{ }^{8} P<0.0001$ relative to control. 

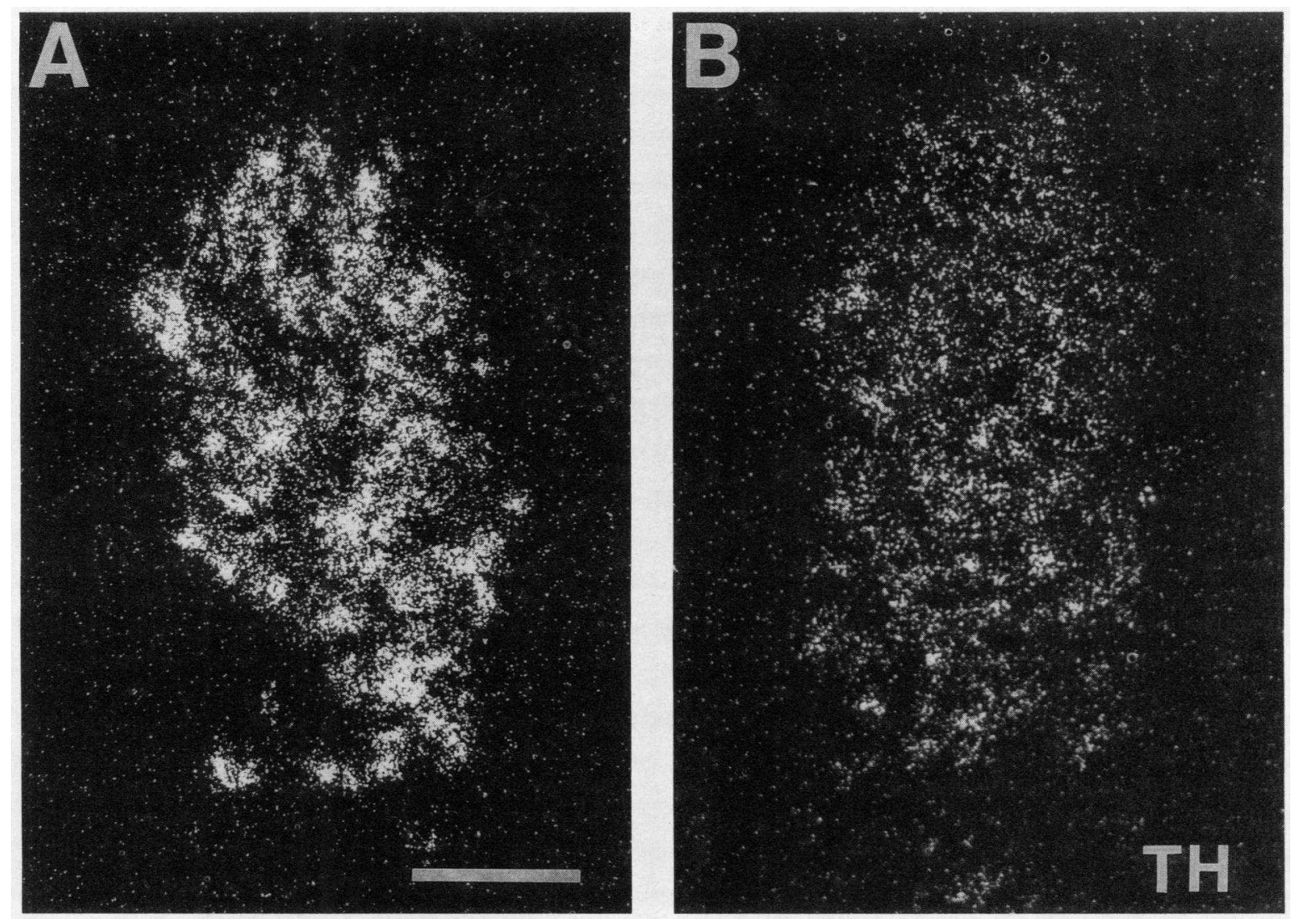

Figure 1. Effects of long-term administration of the antidepressant imipramine $(5 \mathrm{mg} / \mathrm{kg}$, i.p., daily for 8 wk) on tyrosine hydroxylase (TH) mRNA levels in the locus coeruleus of rat brain. Darkfield photomicrographs show the autoradiographic distribution of TH mRNA in the locus coeruleus of control $(A)$ and 8-wk imipramine-treated $(B)$ rats. Autoradiographic silver grains appear white. Bar, $140 \mu \mathrm{m}$.

but were not altered in the intermediate lobe (Fig. 4, $A$ and $B$ ). GR mRNA levels were decreased in both the anterior and intermediate lobes of the pituitary (Fig. 4, $C$ and $D$ ). The reduction in gene expression of GR was greater than that of POMC. Gene expression of MR was not altered after 2 or 8 wk of imipramine in either the anterior or intermediate lobes of the pituitary (Table I).

Effects of daily imipramine on plasma drug and hormone levels, body weight, and adrenal gland weight. The decrease in mRNA levels of CRH in the PVN and POMC in the anterior pituitary of animals treated with imipramine for $8 \mathrm{wk}$ was associated with a $30 \%$ reduction in plasma ACTH, normal corticosterone levels (Table II), and a $17 \%$ increase in the wet weight of the adrenal glands $(20.2 \pm 1.9 \mathrm{mg}, P<0.01$, relative to control $17.2 \pm 1.5 \mathrm{mg}$ ). Plasma levels of imipramine did not differ after 2 or 8 wk of drug administration, whereas desipramine levels were increased threefold at the 8 -wk time point. After $8 \mathrm{wk}$ of imipramine treatment plasma drug levels $(200 \mathrm{ng} / \mathrm{ml}$, imipramine plus desipramine) were within the range of clinically-effective concentrations (22). Body weight was not significantly affected by 8 wk of daily imipramine administration (Table II).

To determine if the effects of chronic imipramine were dose related, the drug was administered for 2 wk at a higher dose of $20 \mathrm{mg} / \mathrm{kg}$. Plasma imipramine levels were 3.5 -fold greater and desipramine levels were 12.5-fold greater than those measured in rats given the $5 \mathrm{mg} / \mathrm{kg}$ dose for 2 wk. Plasma ACTH was decreased by $37 \%$ in rats given $20 \mathrm{mg} / \mathrm{kg}$ of imipramine for 2 wk. No changes were seen in mRNA levels of TH, CRH, POMC, MR, or GR in the brain regions listed in Table $\mathrm{I}$.

\section{Discussion}

Long-term imipramine administration decreased the gene expression of CRH in the PVN and TH in the LC. In addition, long-term imipramine treatment increased the gene expression of MR but not GR in the hippocampus and decreased the expression of POMC and GR in the anterior pituitary. The imipramine-induced decrease in CRH mRNA levels in the PVN and POMC mRNA levels in the anterior pituitary were associated with physiological changes consisting of decreased plasma pituitary ACTH secretion, normal plasma corticosterone levels, and increases in the weight of the adrenal glands. With the exception of a small decrease in TH expression in the LC after 2 wk of drug, these imipramine-induced changes were entirely time dependent, and did not occur with the short-term daily administration of imipramine.

Changes in mRNA levels induced by imipramine may result in altered peptide content or receptor number in specific brain regions. The imipramine-induced decreases in mRNA levels of CRH in the PVN and POMC in the anterior pituitary parallel the decrease in plasma levels of ACTH. These results are consistent with a reduction in secretory activity of $\mathrm{CRH}$ neurons in the PVN and corticotrope cells in the pituitary.

We cannot definitively account for the mechanism of the 

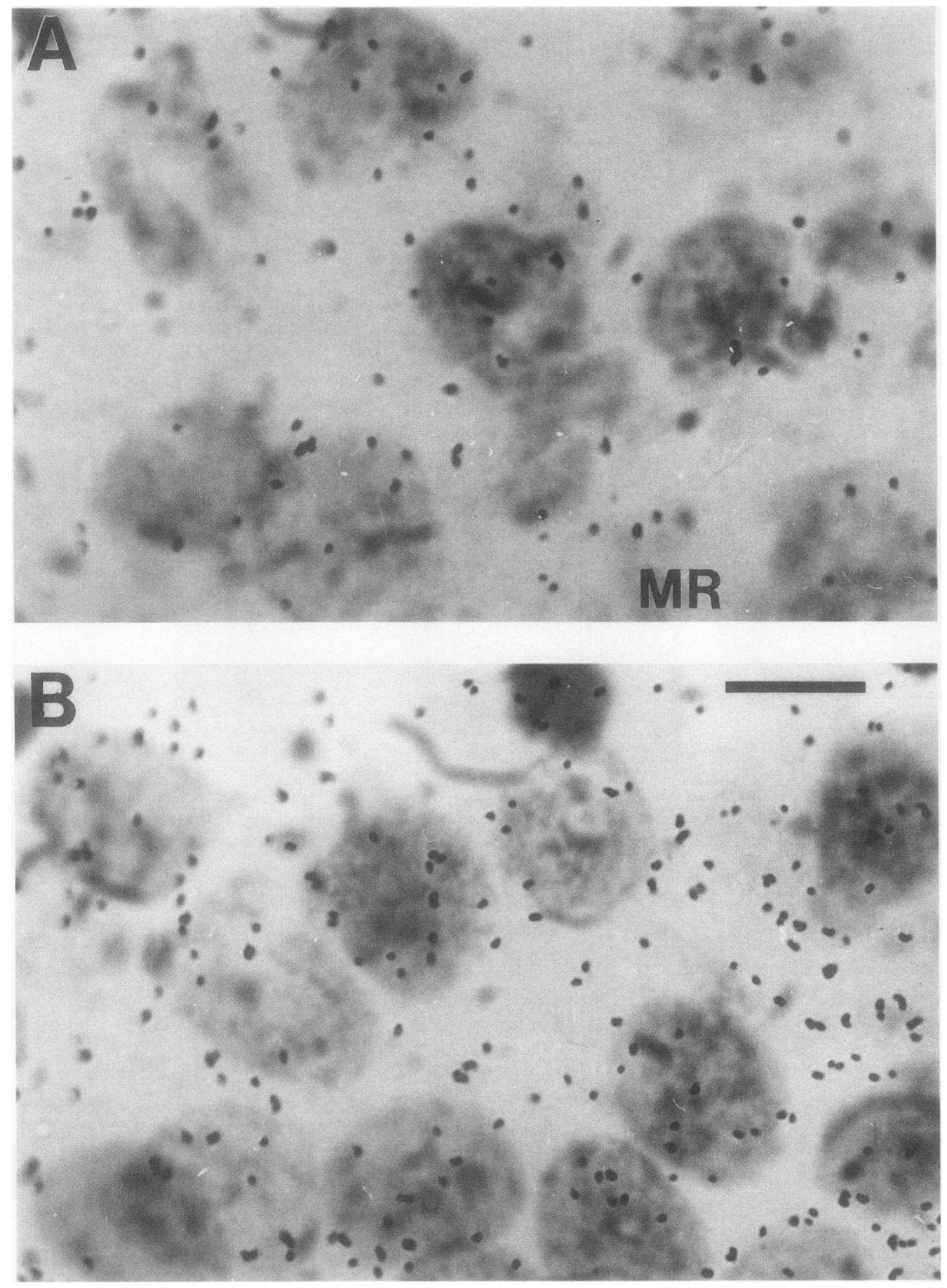

Figure 2. Effects of imipramine on mineralocorticoid receptor (MR) mRNA levels in the hippocampus. Highmagnification brightfield photomicrographs show the autoradiographic distribution of MR mRNA in CAI neurons in the hippocampus of control $(A)$ and 8-wk imipramine-treated $(B)$ rats. Black silver grains mark locations and amounts of probe hybridized in pyramidal neurons. Bar, $10 \mu \mathrm{m}$.

imipramine-induced decrease in CRH gene expression in the PVN. However, MR and GR in the hippocampus appear to mediate the negative feedback effects of steroids on the HPA axis. In the hippocampus, MR has a high affinity for corticosterone and appears to mediate the negative feedback effects of the low levels of corticosterone on the basal circadian rhythm of pituitary-adrenal secretion, whereas GR has a lower affinity for glucocorticoids and appears to regulate the secretion of CRH and ACTH associated with stress $(9,10,17,23)$. In our study, the decrease in imipramine-induced expression of $\mathrm{CRH}$ in the PVN of unstressed rats is compatible with a preferential effect of imipramine on gene expression of MR rather than GR. Moreover, daily imipramine administration $(20 \mathrm{mg} / \mathrm{kg}$, i.p.) for $12 \mathrm{~d}$ is reported to abolish the basal circadian pattern of corticosterone secretion in rats (24).

An additional possible mechanism for the imipramine-induced decrease in gene expression of CRH in the PVN is the early imipramine-induced decrease in expression of $\mathrm{TH}$ in the LC. Noradrenergic fibers from the LC and other brainstem nuclei project to terminal fields in the parvocellular region of 

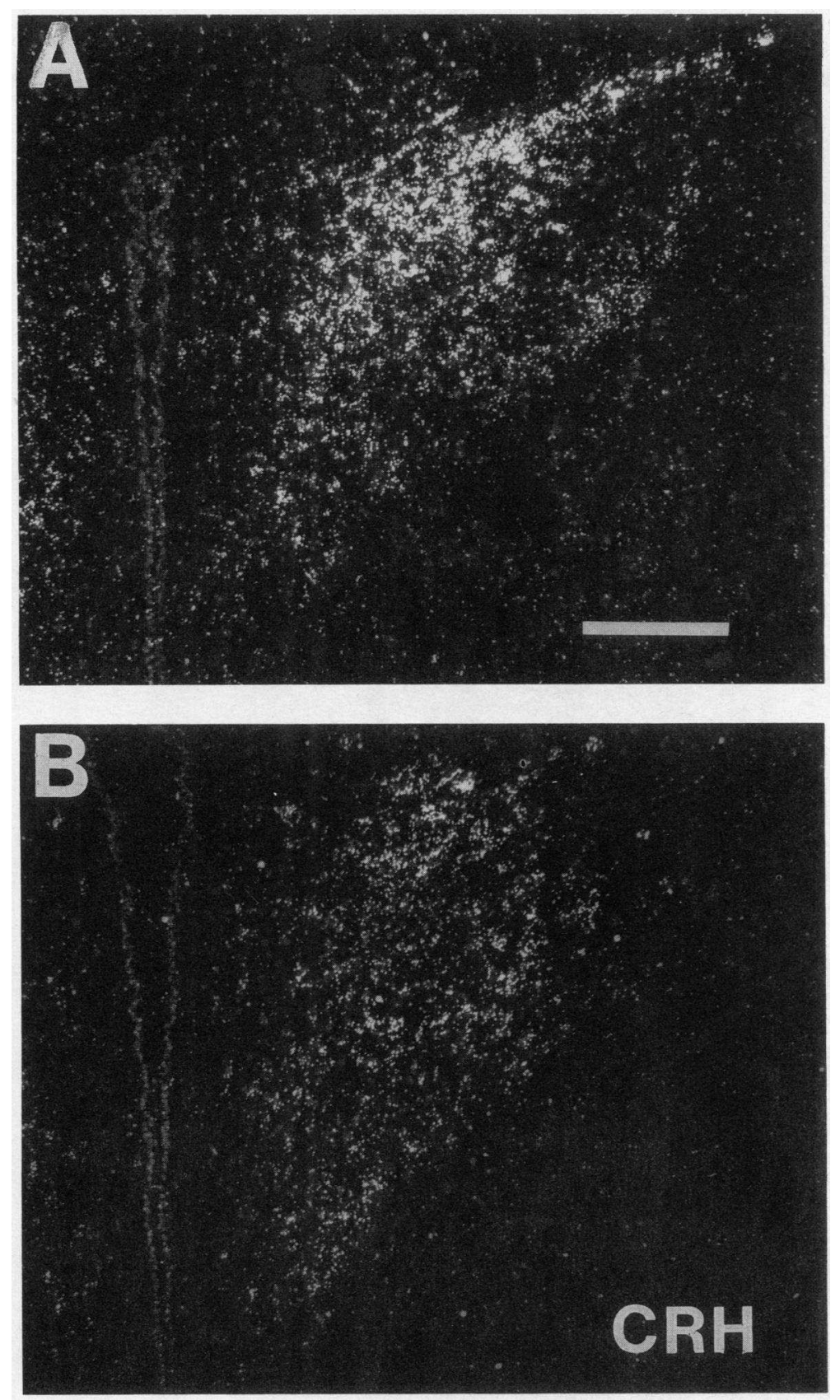

Figure 3. Effects of imipramine on corticotropin-releasing hormone (CRH) mRNA levels in the hypothalamus. Darkfield photomicrographs show CRH mRNA hybridized in the paraventricular nucleus of control $(A)$ and 8-wk imipramine-treated $(B)$ rats. CRH mRNA levels are decreased in the parvocellular region of the nucleus. Bar, $350 \mu \mathrm{m}$. the PVN (25). NE is a potent stimulus of hypothalamic CRH release (25-28). Because tricyclic antidepressants decrease the firing rate of LC neurons, the imipramine-induced decrease in TH gene expression may be involved in mediating the decrease in CRH gene expression.

Finally, we cannot rule out the influence of a direct effect of imipramine on adrenal responsiveness, as evidenced by an imipramine-induced increase in adrenal weight, as a factor contributing to the decrease in message levels of CRH in the PVN, and POMC and GR in the anterior pituitary. Increased adrenal weight and responsiveness to ACTH suggests that for a given basal level of corticosterone, less CRH and ACTH would be required to promote corticosterone secretion from hyperplastic adrenal glands. Our finding of a reduction in plasma ACTH levels in the context of normal basal corticosterone levels is compatible with the formulation.

The most consistent finding in biological psychiatry is that patients with major melancholic depression show a concomitant and at times profound activation of brain CRH and LCNE systems that resolve with successful administration of tricyclic antidepressants administered over a prolonged period of time. In fact, tricyclic antidepressants are particularly effective in treating depressions associated with significant hypercortisolism (6). In the present paper, we have shown that long-term but not short-term imipramine administration to unstressed, eucortisolemic rats decreases the gene expression of $\mathrm{CRH}$ in the PVN and TH in the LC, and we suggest that such effects may be relevant to the therapeutic efficacy of imipramine in 

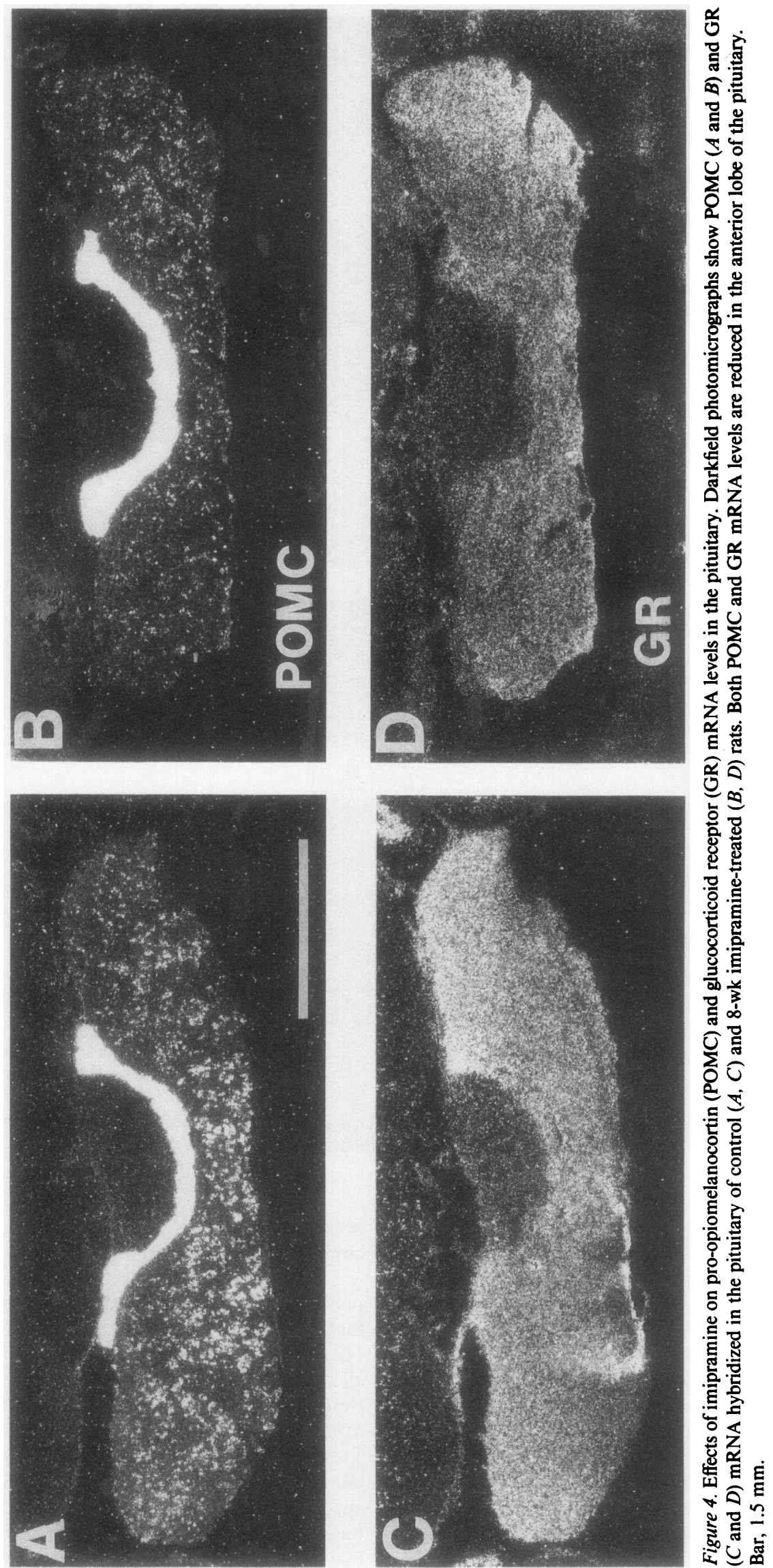
Table II. Plasma Drug Levels, Hormone Levels, and Body Weights in Control and Imipramine-treated Rats

\begin{tabular}{lccc}
\hline & Control & $\begin{array}{c}\text { Imipramine } \\
2 \mathrm{wk}\end{array}$ & $\begin{array}{c}\text { Imipramine } \\
8 \mathrm{wk}\end{array}$ \\
\hline Imipramine $(\mathrm{ng} / \mathrm{ml})$ & & $42 \pm 31$ & $61 \pm 34$ \\
Desipramine $(\mathrm{ng} / \mathrm{ml})$ & & $41 \pm 15$ & $139 \pm 70^{\ddagger}$ \\
ACTH $(\mathrm{pg} / \mathrm{ml})$ & $222 \pm 68$ & $192 \pm 83$ & $157 \pm 39^{*}$ \\
Corticosterone $(\mathrm{ng} / \mathrm{ml})$ & $136 \pm 72$ & $251 \pm 164$ & $131 \pm 96$ \\
Body weight $(\mathrm{g})$ & $500 \pm 30$ & $352 \pm 34$ & $438 \pm 50$ \\
& & & \\
\hline
\end{tabular}

Values are the mean and SD $(n=6)$. Initial body weights were $310 \pm 25 \mathrm{~g}$ for the control group, $311 \pm 26 \mathrm{~g}$ for the 2-wk imipraminetreated group and $314 \pm 33 \mathrm{~g}$ for the 8-wk imipramine-treated group. Body weight of the control group is measured at $8 \mathrm{wk}{ }^{*} P<0.01$ relative to the respective 2 -wk or 8 -wk saline-injected control; ${ }^{\ddagger} P<0.05$ relative to the 2-wk experimental group.

major depression. Future studies on the effects of long-term administration of other classes of antidepressants will provide support for the generality of these findings.

\section{Acknowledgments}

We thank Sam Listwak (Clinical Neuroendocrinology Branch, National Institute of Mental Health) for performing the RIA and HPLC assays of plasma hormone and drug levels.

\section{References}

1. Baker, G. B., and A. J. Greenshaw. 1989. Effects of long-term administration of antidepressants and neuroleptics on receptors in the central nervous system. Cell. Mol. Neurobiol. 9:1-44.

2. Nemeroff, C. B., E. Widerlöv, G. Bissette, H. Walléus, I. Karlsson, K. Eklund, C. D. Kilts, P. T. Loosen, and W. Vale. 1984. Elevated concentrations of CSF corticotropin-releasing factor-like immunoreactivity in depressed patients. Science (Wash. DC). 226:1342-1343.

3. Gold, P. W., D. L. Loriaux, A. Roy, M. A. Kling, J. R. Calabrese, C. H. Kellner, L. K. Nieman, R. M. Post, D. Pickar, W. Gallucci, P. Avgerinos, S. Paul, E. H. Oldfield, J. Cutler, and G. P. Chrousos. 1986. Responses to corticotropinreleasing hormone in the hypercortisolism of depression and Cushing's disease. Pathological and diagnostic implications. N. Engl. J. Med. 314:1329-1335.

4. Roy, A., D. Pickar, S. Paul, A. Doran, G. P. Chrousos, and P. W. Gold. 1987. CSF corticotropin-releasing hormone in depressed patients and normal control subjects. Am. J. Psych. 144:641-645.

5. Siever, L. J., and K. L. Davis. 1985. Overview: toward a dysregulation hypothesis of depression. Am. J. Psych. 142:1017-1031.

6. Gold, P. W., F. K. Goodwin, and G. P. Chrousos. 1988. Clinical and biochemical manifestations of depression. Relation to neurobiology of stress. $N$. Engl. J. Med. 319:348-353, 413-420.

7. McEwen, B. S., J. M. Weiss, and L. S. Schwartz. 1968. Selective retention of corticosterone by limbic structures in rat brain. Nature (Lond.). 220:911-912.

8. Sapolsky, R. M., L. C. Krey, and B. S. McEwen. 1984. Glucocorticoid-sensitive hippocampal neurons are involved in terminating the adrenocortical stress response. Proc. Natl. Acad. Sci. USA. 81:6174-6177.

9. Reul, J. H., and E. R. deKloet. 1985. Two receptor systems for corticoste- rone in brain: microdistribution and differential occupation. Endocrinology. 117:2505-2511.

10. Herman, J. P., M. K.-H. Schåfer, E. A. Young, R. Thompson, J. Douglass, H. Akil, and S. J. Watson. 1989. Evidence for hippocampal regulation of neuroendocrine neurons of the hypothalamo-pituitary-adrenocortical axis. $J$. Neurosci. 9:3072-3082.

11. Chrousos, G. P., H. M. Schulte, E. H. Oldfield, P. W. Gold, J. Cutler, and D. L. Loriaux. 1984. The corticotropin releasing factor stimulation test. $N$. Engl. J. Med. 310:622-626.

12. Rop, P. P., T. Conquy, F. Gouenzo, A. Viala, and F. Grimaldi. 1986. Determination of metapramine, imipramine, trimipramine, and their major metabolites in plasma by reversed phase column liquid chromatography. J. Chromatogr. 375:339-347.

13. Jingami, H., N. Mizuno, H. Takahashi, S. Shibahara, Y. Furutani, H. Imura, and S. Numa. 1985. Cloning and sequence analysis of cDNA for rat corticotropin-releasing factor precursor. Fed. Eur. Biochem. Soc. Lett. 191:6366.

14. Drouin, J., M. Chamberland, J. Charron, L. Jeannotte, and M. Nemer. 1985. Structure of the rat pro-opiomelanocortin (POMC) gene. FEBS (Fed. Eur Biochem. Soc.) Lett. 193:54-58.

15. Grima, B., A. Lamouroux, F. Blanot, N. F. Biquet, and J. Mallet. 1985. Complete coding sequence of rat tyrosine hydroxylase mRNA. Proc. Natl. Acad. Sci. USA. 82:617-621.

16. Miesfeld, R., S. Rusconi, P. J. Godowski, B. A. Maler, S. Okret, A. C. Wikström, J.-Å. Gustafsson, and K. R. Yamamoto. 1986. Genetic complementation of a glucocorticoid receptor deficiency by expression of cloned receptor cDNA. Cell. 46:389-399.

17. Arriza, J. L., R. B. Simerly, L. W. Swanson, and R. M. Evans. 1988. The neuronal mineralocorticoid receptor as a mediator of glucocorticoid response. Neuron. 1:887-900.

18. Young, W. S., III, T. I. Bonner, and M. R. Brann. 1986. Mesencephalic dopamine neurons regulate the expression of neuropeptide mRNAs in the rat forebrain. Proc. Natl. Acad. Sci. USA. 83:9827-9831.

19. Whitfield, H. J., Jr., L. S. Brady, M. A. Smith, E. Mamalaki, R. J. Fox, and M. Herkenham. 1990. Optimization of cRNA probe in situ hybridization methodology for localization of glucocorticoid receptor mRNA in rat brain: a detailed protocol. Cell. Mol. Neurobiol. 10:145-157.

20. Herkenham, M., and C. B. Pert. 1982. Light microscopic localization of brain opiate receptors: a general autoradiographic method which preserves tissue quality. J. Neurosci. 2:1129-1149.

21. Herkenham, M. 1988. Molecular Neuroanatomy. F. W. Van Leeuwen, R. M. Buijs, C. W. Pool, and O. Pach, editors. Elsevier Science Publishers, New York. 111-120.

22. Davis, J. M., and A. H. Glassman. 1989. Comprehensive Textbook of Psychiatry. 5th ed. H. I. Kaplan and B. J. Sadock, editors. Williams and Wilkins, Baltimore. 1627-1654.

23. Ratka, A., W. Sutanto, M. Bloemers, and E. R. de Kloet. 1989. On the role of brain mineralocorticoid (type I) and glucocorticoid (type II) receptors in neuroendocrine regulation. Neuroendocrinology. 50:117-123.

24. Shimoda, K., N. Yamada, K. Ohi, T. Tsujimoto, K. Takahashi, and S. Takahashi. 1988. Chronic administration of tricyclic antidepressants suppresses hypothalamo-pituitary-adrenocortical activity in male rats. Psychoneuroendocrinology. 13:431-440.

25. Plotsky, P. M., E. T. Cunningham, and E. P. Widmaier. 1989. Catecholaminergic modulation of corticotropin-releasing factor and adrenocorticotropin secretion. Endocrine Rev. 10:437-458.

26. Plotsky, P. M. 1987. Facilitation of immunoreactive corticotropin-releasing factor secretion into the hypophysial-portal circulation after activation of catecholaminergic pathways or central norepinephrine injection. Endocrinology. 121:924-930.

27. Szafarczyk, A., F. Malaval, A. Laurent, R. Gibaud, and I. Assenmacher 1987. Further evidence for a central stimulatory action of catecholamines on adrenocorticotropin release in the rat. Endocrinology. 121:883-892.

28. Calogero, A. E., W. T. Gallucci, G. P. Chrousos, and P. W. Gold. 1988. Catecholamine effects upon rat hypothalamic corticotropin-releasing hormone secretion in vitro: potential clinical implications. J. Clin. Invest. 82:839-846. 